\title{
Flow Cytometric Analysis of Peripheral T lymphocyte Subpopulations in Psoriasis
}

\author{
Hanan M.A. Darwish, Nahla M. Abd EL-Aziz* , and \\ Fatma M. EL-Marzouky. \\ Departments of Dermatology and Venereology \& Clinical pathology \\ Faculty of Medicine for Girls AL-AZhar University
}

\begin{abstract}
Background : Psoriasis is a common inflammatory skin disorder, has received attention as a target for new pathogenesis and oriented therapies .

Autoimmunity and $\mathrm{T}$ lymphocyte subsets are suggested to be involved in the development of psoriasis.

The aim of this work is to asses the role of $\mathrm{T}$ lymphocyte subsets in the pathogenesis of psoriasis .

Material And Methods :We investigated the peripheral blood lymphocyte subpopulations obtained from psoriatic patient before and after treatment and from healthy controls, using two colour flow cytometry.

Results :We found highly significant suppression of total $\mathrm{CD}_{3}{ }^{+} \mathrm{T}$ Cells and $\mathrm{CD}_{3}{ }^{+} \mathrm{CD}_{56}{ }^{+}$ NKT lymphocytes in psoriatic patient as compared to control. Also, we observed significant reduction of $\mathrm{T}$ helper cells in patients as compared to control.

Conclusion : The highly significant reduction of $\mathrm{CD}_{3}{ }^{+} \mathrm{T}$ cell and $\mathrm{CD}_{3}{ }^{+} \mathrm{CD}_{56}{ }^{+} \mathrm{NKT}$ lymphocytes proved their actively involvement in the development of psoriasis.
\end{abstract}

\section{Introduction and aim of the work:}

Psoriasis is a common genetically determined inflammatory and proliferative disease of the skin (comp RDR,1998).It occurs in $1-3 \%$ of the world's population (Ortonne,1999). The etiology and pathogenesis of psoriasis undergo intense investigation during the past decade (Kenneth et al., 2003)

There are characteristic features of the disease which suggest an immunological mediated process. (Mends et al., 2000)

Several direct and indirect evidence suggest that $\mathrm{T}$ lymphocytes play a crucial role in the pathogenesis of psoriasis (Paul et al., 2001) .

The presence of $\mathrm{T}$ helper cells, that secrete type 1 cytokines [ IFN- $\gamma, \mathrm{TNF} \alpha$ ] was demonstrated in psoriatic skin lesions. (Nickoloff., 1999)
The generation of psoriasis skin lesion has been described in animal models by a process based on $\mathrm{T}$ cell regulation. (Schon et al .,2003) In addition, the role of $\mathrm{T}$ lymophocytes as key affector cells is strongly supported by work from various groups in xanthotransplantation models, injection of activated $\mathrm{T}$ lymphocytes from the same patient onto severe combined immunodeficiency mice resulted in the generation of psoriatic lesions ( Boyman et al., 2004)

Antipsoriatic therapy acts on dual populations of cytokines secreting $\mathrm{T}$ helper cells $\left(\mathrm{Th}_{1}\right.$ cells secrete proinflammatory cytokines [IFN- $\left.\gamma, \mathrm{TNF} \alpha \quad \mathrm{IL}_{2}\right]$ and $\mathrm{Th}_{2}$ which secrete inhibitory cytokines $\left[\mathrm{IL}_{4}, \mathrm{IL}_{10}\right]$. (Austin et al., 1999) .

Induction of immunodeviation of 
psoriasis in the form of $\mathrm{Th}_{2}$ cytokines $\mathrm{IL}_{10}$ or $\mathrm{IL}_{4}$, down regulate the activity of $\mathrm{Th}_{1}$ and reduce psoriatic lesions by $60 \%-80 \%$. (Asadullah et al., 1999 ) and (Ghoreschik et al., 2003) .

Natural killers $\mathrm{T}$ cells might have a role in the imbalance between $\mathrm{Th}_{1}$ and $\mathrm{Th}_{2}$ cells (Seder et al., 1998) NK cell clones secrete type 1 , type 2 or both types of cytokines which could influence the differentiation of $\mathrm{Th}_{0}$ towards $\mathrm{Th}_{1}$ or $\mathrm{Th}_{2}$ cells (Doherty et al., 1999) $\mathrm{CD}_{3}, \mathrm{CD}_{56}$ cells represent one of the NK T cell populations. CD3 CD56 NK T cell were significantly decreased in peripheral blood of patients with $\mathrm{Th}_{1}$ mediated autoimmune disease (Yanagihara et al., 1999).

The aim of our study is to asses the role of different $T$ lymphocyte subsets in the pathogenesis of psoriasis.

\section{Patients and methods}

\section{Patients profile :}

Peripheral blood samples of 19 patients with psoriasis (two eythrodermic, 17 chronic plaque psoriasic ) was obtained before and after treatment from all patients. Therapeutic modalities included mono therapy and combined therapeutic regimens.

[PUVA(Psoralen +narrow band U.V.B (311), methotrexate].

After treatment, blood samples were taken at the time when the applied treatment regimen had been completed.

The control group consisted of 10 healthy persons, with informed consent for use in the study. In the control group nobody took any medicine and nobody suffered from any known acute or chronic disease.

\section{Materials}

Anti $\mathrm{CD}_{4}$ FITC (Clone MT 310 ), anti $\mathrm{CD}_{8} \mathrm{PE}$ and anti $\mathrm{CD}_{56}$ FITC, Anti $\mathrm{CD}_{3}$ FITC and anti $\mathrm{CD}_{3}$ PE [ Clone UCHTI]. Immunostaining and flowcytometry:

Peripheral blood, anticoagulated with EDTA, was collected each blood sample
(50 Microlitres) was stained with two monoclonal antibodies one conjugated with FITC and the other with PE (20 Microlitres from each) at room temperature, in the dark for $20 \mathrm{~min}$. Erythrocytes were lysed with lysing solution. After two washes with PBS [phosphate buffer saline], the cells were resuspended in PBS for immediate analysis or were fixed $2 \%$ paraformaldehyde over night storage before analysis then analysed by flowcytometer in a Beckman coulter. EPICS XL flowcytometer equipped with argon ion laser $488 \mathrm{~nm}$, soft system II ver 3

\section{Stastical analysis:}

Data was expressed as mean $\pm \mathrm{SD}$ comparison between 2 means was performed using student's test, $\mathrm{P}$ value < 0.05 was considered significant, whereas $P$ value $<0.01$ was considered highly significant.

\section{Results:}

The lymphocyte subsets of psoriatic patient before and after treatments and in healthy control were analysed.

It has been shown that the percentage of total $\mathrm{CD}_{3}^{+} \mathrm{T}$ lymphocytes was highly significantly decreased in patient before treatment as compared to healthy control ( $57.89 \pm 6$ in patient before treatment versus $72.09 \pm 2.16$ in healthy control, $\mathrm{P}=$ $0.0000)$ (Table 1) .

Similarly, the percentage of $\mathrm{CD}_{3}^{+}$, $\mathrm{CD}_{56}{ }^{+} \mathrm{T}$ lymphocytes were highly significantly reduced in psoriatic patient before treatment in comparing to healthy control $(1.29 \pm 0.4$ before treatment versus $4.58 \pm 0.7$ in control, $\mathrm{P}=0.0000)$ (Table 1)

A suppression in the percentage of $\mathrm{T}$ helper lymphocytes was observed in psoriatic patient before treatment as compared to control $(31.42 \pm 3.99$ before treatment versus $39.13 \pm 2.15$ in control, $\mathrm{P}<0.0001)$ (Fig1)

The cytotoxic $\mathrm{CD}_{8}$ lymphocytes showed non-significant reduction in patient before treatment versus healthy control $(25.51 \pm 4.25$ before treatment versus 29.17 
\pm 1.83 in healthy control, $\mathrm{P}=0.024$ ) (Table 1).

Comparing the lymphocyte subsets of patients before and after treatment showed that both total $\mathrm{CD}_{3} \mathrm{~T}$ lymphocytes and $\mathrm{CD}_{3}{ }^{+}, \mathrm{CD} 6^{+}$cells were significantly increased in patient after treatment as compared to patient before treatment. (The percentage of total $\mathrm{CD}_{3}{ }^{+}$before treatment
$57.89 \pm 6$ versus $63.46 \pm 5.5$ after treatment, $\mathrm{P}=0.0000$ ) (Table 2 , Fig 1)

$\left(\mathrm{CD}_{3}{ }^{+}, \mathrm{CD}_{56}{ }^{+}\right.$lymphocytes before treatment $1.29 \pm 0.4$ versus $1.89 \pm 0.5$ after treatment $\mathrm{P}<0.0001$ ) (Fig 2)

No significant change was observed in the percentage of $\mathrm{CD}_{4}$ and $\mathrm{CD}_{8} \mathrm{~T}$ lymphocytes, before and after treatment. (Table2)

Table (1) :- Shows the percentage of lymphocyte subsets in psoriatic patients before treatment and in healthy controls.

\begin{tabular}{|l|c|c|c|}
\hline & Control & $\begin{array}{c}\text { Patient before } \\
\text { treatment }\end{array}$ & P value \\
\hline $\mathbf{C D}_{\mathbf{3}}{ }^{+}$ & $72.09 \pm 2.16$ & $57.89 \pm 6$ & 0.0000 \\
\hline $\mathbf{C D}_{\mathbf{3}}{ }^{+} \mathbf{C D}_{\mathbf{5 6}}{ }^{+}$ & $4.58 \pm 0.7$ & $1.29 \pm 0.4$ & 0.0000 \\
\hline $\mathbf{C D}_{\mathbf{4}}$ & $39.13 \pm 2.15$ & $31.42 \pm 3.99$ & $<0.0001$ \\
\hline $\mathbf{C D}_{\mathbf{8}}$ & $29.17 \pm 1.85$ & $25.51 \pm 4.25$ & 0.0243 \\
\hline
\end{tabular}

Table (2):- Shows comparative study between lymphocytes subsets before and after treatments of psoriatic patients.

\begin{tabular}{|l|c|c|c|}
\hline & Before & $\begin{array}{c}\text { Patient after } \\
\text { treatment }\end{array}$ & P value \\
\hline $\mathbf{C D}_{\mathbf{3}}{ }^{+}$ & $57.89 \pm 6$ & $63.46 \pm 5.5$ & 0.0000 \\
\hline $\mathbf{C D}_{\mathbf{3}}{ }^{{ }^{+} \mathbf{C D}_{\mathbf{5 6}}{ }^{+}}$ & $1.29 \pm 0.4$ & $1.89 \pm 0.5$ & $<0.0001$ \\
\hline $\mathbf{C D}_{\mathbf{4}} \mathbf{C D}_{\mathbf{8}}$ & $31.42 \pm 3.99$ & $32.28 \pm 3.10$ & 0.0074 \\
\hline
\end{tabular}


Flow cytometric analysis of peripheral....................

( Fig 1 ) CD3,CD4, CD8 \& CD3 56 AMONG STUDIED GROUPS

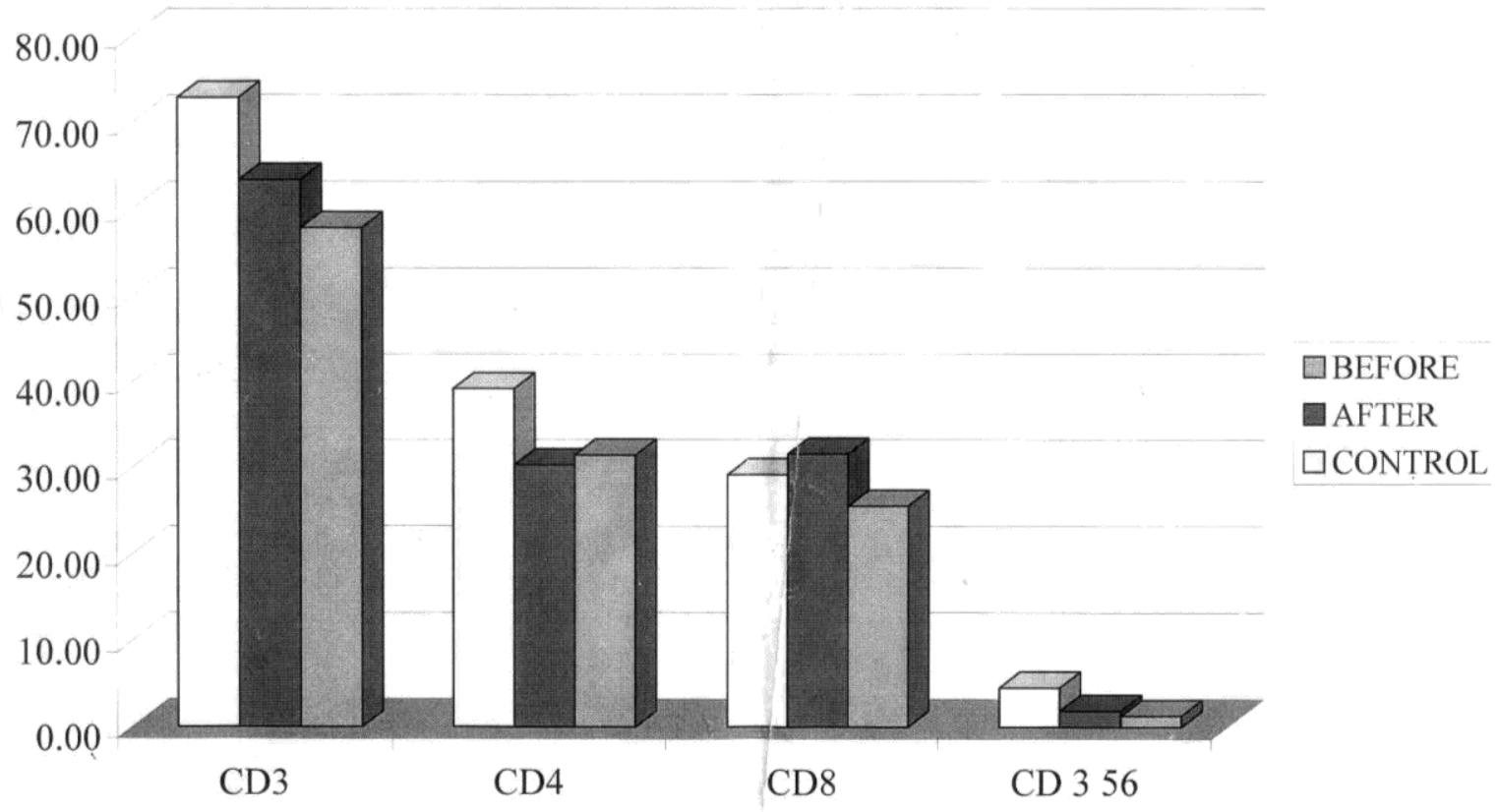

( Fig 2 ) CD3 56 AMONG STUDIED GROUPS

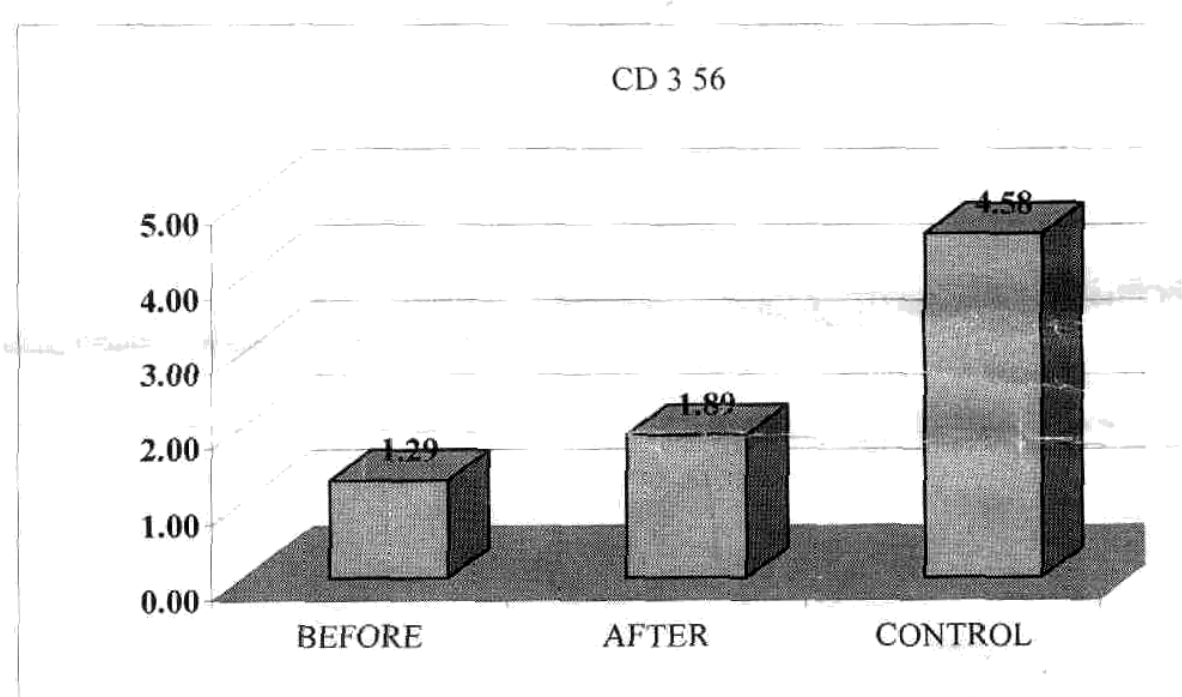




\section{Discussion:}

Psoriasis is an instructive model for studying interactions of immigration immunocytes with resident epithelial and mesenchymal cell. This disease throw high lights on the pathogenic importance of $\mathrm{T}$ cells (Spadro et al., 2004)

In our current study, we assessed the levels of Total $\mathrm{CD}_{3}{ }^{+} \mathrm{T}$ lymphocytes, $\mathrm{CD}_{3}{ }^{+}$ $\mathrm{CD}_{56}{ }^{+} \mathrm{NKT}$ cells, $\mathrm{CD}_{4}{ }^{+} \mathrm{T}$ helper cells and $\mathrm{CD}_{8}{ }^{+}$cytotoxic $\mathrm{T}$ Cells in psoriatic patients before and after treatment in comparing to the control group. We observed highly significant reduction in psoriatic $\mathrm{CD}_{3}{ }^{+} \mathrm{T}$ lymphocytes before and after treatment as compared to their levels in healthy control group. Since we didn't study $\mathrm{CD}_{3}{ }^{+} \mathrm{T}$ lymphocytes in the skin, we couldn't exclude that the reduction of psoriatic $\mathrm{CD}_{3}{ }^{+}$ $\mathrm{T}$ lymphocytes might come from their differential homing to skin. Michael et al. (2005). demonstrated the complex pathological tissue alterations in psoriatic skin and showed a mixed inflammatory infiltrate that contains activated $\mathrm{CD}_{3}{ }^{+} \mathrm{T}$ lymphocytes within psoriatic dermis and epidermis.

Another very important finding in our study was highly significant reduction in the number of $\mathrm{CD}_{3}{ }^{+} \mathrm{CD}_{56}{ }^{+} \mathrm{T}$ lymphocytes in peripheral blood of psoriatic patient before treatment in comparing to healthy control and significantly increased after different therapies but remain significantly lower than those found in healthy control, this in agreement with KORECK et al. (2002) who suggested that the decrease of $\mathrm{CD}_{3}{ }^{+} \mathrm{CD}_{56}{ }^{+}$lymphocytes may represent an intrinsic characteristic feature of psoriatic patient. This hypothesis is supported by the fact the $\mathrm{CD}_{3}{ }^{+} \mathrm{CD}_{56}{ }^{+}$lymphocytes of psoriatic patient after treatment didn't reach the values found in healthy control.

Another possible explanation may be represented by early activation of $\mathrm{CD}_{3}^{+}$ $\mathrm{CD}_{56}{ }^{+}$lymphocytes by antigen involved in the disease, followed by apoptosis, this is evidenced by Thomas and Kupper. (2005) who showed migratory patterns of $\mathrm{CD}_{3}^{+}$ $\mathrm{CD}_{56}{ }^{+}$lymphocytes to home in the skin and their interaction with psoriatic autoantigen .
The study has also shown a suppression in the proportion of $\mathrm{CD}_{4} \mathrm{~T}$ helper cells in psoriatic patient before treatment in comparing to control. This was explained by Michael et al. (2005) who observed the trafficking pattern of helper $\mathrm{T}$ cells from peripheral blood to psoriatic dermis and epidermis.

\section{Conclusion:}

Our results suggest that reduced total $\mathrm{CD}_{3}{ }^{+} \mathrm{T}$ cells and marked suppression of $\mathrm{CD}_{3}{ }^{+} \mathrm{CD}_{56}{ }^{+} \mathrm{T}$ cells in psoriatic patient can be of importance in the development of psoriasis . As such, it may help in the development of novel immune therapies for psoriasis.

\section{References}

1. Asadullah K, sabat R, Wiese et al., 1999: Interlaukine 10 in cutaneous disorders implication for its pathophysialogical importance and therapeutic use. Arch Dermatol. Res. 291: 628-36

2. Austin L, ozawa M, kikuchi T et al., 1999: the majority epidermal $\mathrm{T}$ cell in psoriasis vulgaris lesions can produce type 1 cytokines, interferon, interlukin 2 and tumor necrosis factor, defining $\mathrm{TC}_{1}$ and $\mathrm{TH}_{1}$ effector populations : type 1 differentiation bias is also measured in circulating blood $\mathrm{T}$ cells in psoriatic patients. J. invest Dermatal., 113 : 752 .

3. Boyman O, Hofti Hp, Gpnard C et al., 2004 : spontaneous development of psoriasis in a new animal model shows an essential role for resident $\mathrm{T}$ cells and tumour necrosis factor - alpha. J. Exp. Med, $199: 731-6$.

4. CompRDR(1998)Psoriasis; Rook textbook of dermatology 6th edition,4(35):15891632.

5. Doherty DG, Norris S, Madrigal L et al., 1999 : the human liver contains multiple population of NK cells, T cells and $\mathrm{CD}_{3}{ }^{+}$ $\mathrm{CD}_{56}{ }^{+} \mathrm{NKT}$ cells with distinct cytotoxic activities Jimmunol., $163: 2314-21$.

6. Ghoreschik, Thomasp, Breits et al., 2003 IL4 therapy induces Th2 responses and 
improves human autoimmune disease. Nat Med., (1) : 40-46.

7. Kenneth B, Gordon. MD, Thomas S. (2003): evolution of Biological therapies for the treatment of psoriasis le Jacq communication skin med2., (5) : 286 - 294.

8. Koreck, A , Suranyi A, szony Bj, Farkas A et al., 2002 : CD3+ CD56+ NKT cells are significantly decreased in the peripheral blood of patient with psoriasis . Clin. Exp immunol., 127 : $176-182$.

9. Mends R, Bromelowk V, westby M et al., 2000: flow cytometric visualization of cytokine production by CD3 CD56 NK cells and CD3 CD56 NK T cells in whole blood. Cytometry., 39:72 - 8

10. Michael P, Schon AD et al ,, 2005 : psoriasis. Engl j Med 325 : $1899-912$.

11. Nickoloff Bj (1999): The immunologic and genetic basis of pasoriasis. Arch dermatol, 135: $1104-10$.

12. Ortonne JP(1999). Recent developments in the understanding of the pathogenesis of psoriasis.Br J. Dermatol ., (140):1-7

13. Paul $\mathrm{K}$, Shon M , Kubitza RC et al., (2001): Role of integrin (CD103 ) B7 for tissue specific epidermal localization of CD8+ T lymphocytes. J. invest. Dermatol., $117: 569-75$.
14. Schon MP, Zollener TM, Boehncke WH. (2003): The molecular basis of lymphocyte recruitment to the skine clues for pathogenesis and selective therapies of inflammatory disorders. J. invest Dermatol; 121: $951-62$

15. Seder R A, Moemann TM. (1998) Differentiation of effctor phemotypes of $\mathrm{CD}_{4}$ and $\mathrm{CD}_{8} \mathrm{~T}$ cells In : Paul WE Fundamental immunology $4^{\text {th }}$ edn, Bethes da. Marylend: Lippincolt - Raven : 879 909 .

16. Spadro A, serivo R, Moretti $\mathbf{T}$ et al., (2004): Natural killer cells and gamma / delta $\mathrm{T}$ cells in synovial fluid and peripheral blood of patients with psoriatic arthritis. Clin. Exp. Rheaumatol., 22 (4) : $389-94$.

17. Thomas S, Kupper MD (2005) : immunologic Targets in psoriasis . Engl $\mathrm{j}$ Med., 34, : 1987 - 1989.

18. Yanagihara Y, Shiozowa K, Takai M (1999) Natural Killer (NK) $T$ cells are significantly decreased in the peripheral blood of patients with rheumatoid arthritis. Clin. Exp. Immunol.,118 : 131-6. 


\section{تحليل خلايا ت الليمفاوية فى الدام

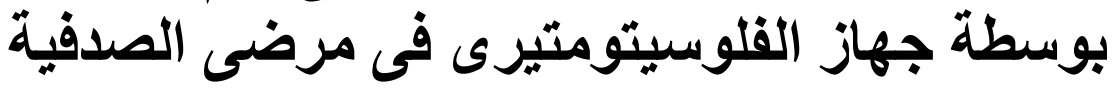

حنان محمد على درويش - نهلة محمد عبد العزيز - فاطمة معتز المرزوقى الإنى قسم الأمر اض الجليدية و التناسلية ـ ق قسم التحاليل الإكلينيكية

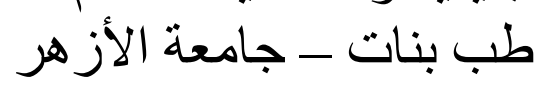

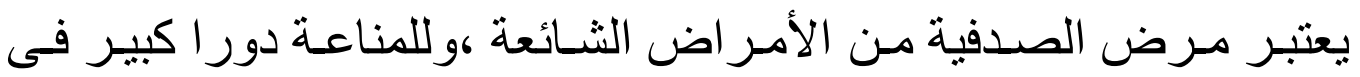

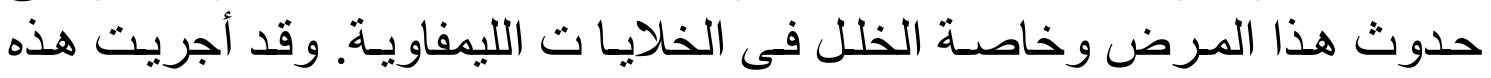

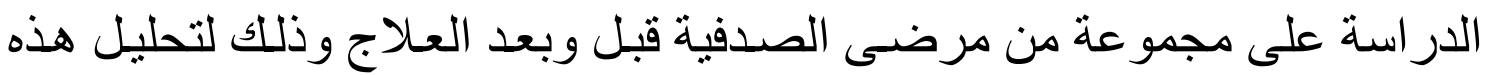

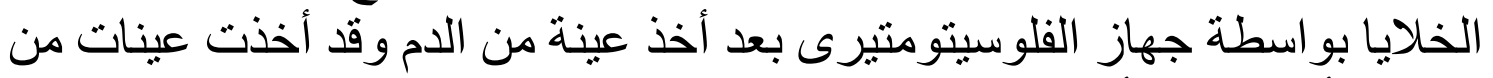

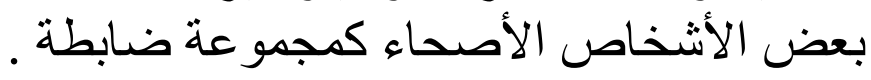
ولقد وجد انخفاض ملحوظ فى

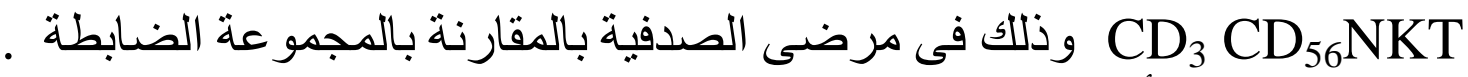

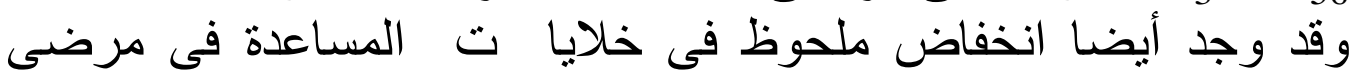

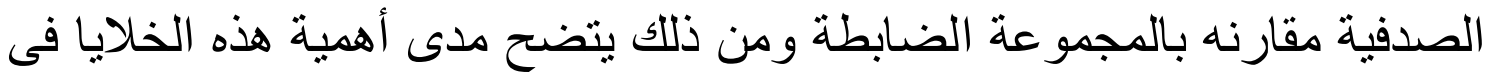
حدوث مرض الصدفية . 